\title{
9B12 水素吸蔵合金を用いたウェアラブルアクチュエータの設計 \\ Design of an Wearable Actuator Using Metal Hydride Alloys
}

\author{
○学 山田 貴史 (北大) 正 井野秀一（北大）＼cjkstart佐藤 満（昭和大）王少遅 (コペル電子) \\ 伊藤 秀明（日本製鋼所）泉 隆（北海道東海大）正 伊福部 達（東大）
}

*Takafumi Yamada (Hokkaido University), Shuichi Ino (Hokkaido University), Mitsuru Sato (Showa University), Shao-Chi Wang (Coper Electronics Ltd.), Hideaki Ito (Japan Steel Works Ltd.),Takashi Izumi (Hokkaido Tohkai University) and Tohru Ifukube (University of Tokyo)

\section{1. はじめに}

現在, モータや空気圧・油圧アクチュエータといった 様々なアクチュエータが日常生活において欠かせない動 力源として活躍している.これらの産業用アクチュエータ は，位置制御の正確さや耐久性に優れているが，出力を大 きくすると容積が大きくなり, ハードウェア的な意味での 柔軟性にも欠けるといった側面がある.

一方, 人間の筋肉は単位面積当たり約 $4 \mathrm{kgf}(40 \mathrm{~N})$ の出 力を出し, 出力重量比が大きく, 柔軟性に優れた高性能の アクチュエータと言える.このような出力重量比が大きく, 柔軟性に富んだ新しいアクチュエータの開発は, ロボット や動力義肢などの分野を始めとして, 社会的にもその要望 が高まっている. 特に, 人体に装着させるようなリハビリ 機器では, 可搬性に加え, ヒトの筇・関節系とのインピー ダンス整合を加味した柔軟性や静寂性に優れるアクチュ エータを利用したシステム設計が求められている.

このような要求を満たすためのものとして, 我々は水素 吸蔵合金(MH 合金)を駆動源としたアクチュエータの開発 に取り組んでいる ${ }^{[1]}$ 。このアクチュエータは, 水素ガス を媒体としているので, アクチュエータ自体に衝突時の負 荷に対する緩衝作用があり，過負荷に対しても強い。また， MH 合金自体が大量の水素ガスを貯蔵し，放出する超小型 ボンべと成り得るので, 装置自体の小型化が可能である. そして,このアクチュエータのベローズ部を従来の金属材 料から高分子複合材料に替え, 軽量・小型・低廉かつウェ アラブルなソフトアクチュエータを提案した ${ }^{[2]}$.

本研究では, 複合フィルム材をべローズに利用した MH ソフトアクチュエータの静的および動的な状態における 基磼特性を調べ, 新しいウェアラブルなアクチュエータと してのリハビリ機器への応用について考察した.

\section{2. 水素吸藏合金アクチュエータ}

\subsection{MH 合金の特性}

水素吸蔵合金とは，合金に対する加熱・冷却により，合 金体積の千倍以上の水素ガスを可逆的に放出・吸収すると いった特性を持った合金のことである。つまり,この特性 により熱エネルギーを機械エネルギーに変換することが 可能となる．この MH 合金は，現在まで様々な種類の合金

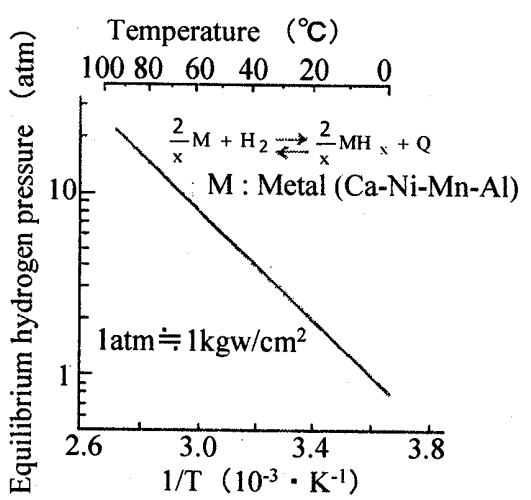

Fig.1 Equilibrium hydrogen pressure of $\mathrm{MH}$ Alloy as a function of temperature

が開発されている.

いま，水素吸藏合金（M）と水素ガス（H）との可逆反 応により金属水化物 $\left(\mathrm{MH}_{\mathrm{x}}\right)$ が形成される過程は（1）式 で表せる.

$$
\frac{2}{\mathrm{X}} \mathrm{M}+\mathrm{H}_{2} \longleftrightarrow \frac{2}{\mathrm{X}} \mathrm{MH}_{\mathrm{X}}+\mathrm{Q}
$$

ここで, $\mathrm{Q}$ は反応熱であり，一定温度ならば，ギブスの 法則より一定圧力で反応が進行する. また，（1）式が平 衡状態にあるとき, 水素圧 $\mathrm{P}$ と温度 $\mathrm{T}$ との間にはVan't Hoff の式が成り立ち, $\log \mathrm{P}$ は $1 / \mathrm{T}$ の一次関数として表すことが できる゙!

図 1 に今回の実験で使用した CaNiMnAl 系の水素吸蔵 合金の平衡水素圧と温度の関係を示す.この図より, 常温 の範囲において平衡水素圧は $1 \mathrm{~atm}$ 程度であることが分か る.したがって，人体への装着を考虑したときに，MHの 反応熱により火傷を負う危険性㹥少ないといえる.

\subsection{MHモジュール}

MH 合金に対する加熱・冷却はペルチェ素子を用いて行 った.これにより, 電気的に水素の放出・吸収を促し, 圧 力の制御ができるといった利点が生じる，そして，MH 合 金とペルチェ素子を密閉容器内に設置しモジュール化す ることで, コンプレッサとしての機能を持つことができる. この MH モジュールを駆動源とすることにより軽量, 小型, そしてウェアラブルなアクチュエータを設計することが できる.

密閉容器は $\phi 82 \mathrm{~mm}$, 幅 $20 \mathrm{~mm}$ の円柱形で, 内部には 6 


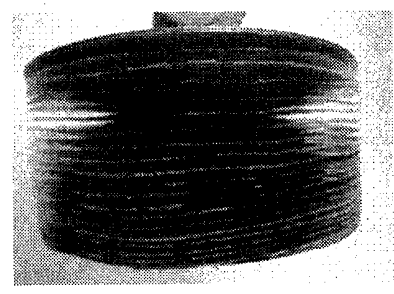

Fig.2 Soft-bellows made of a laminate film

Table1 Comparison soft-bellows with metal-bellows

\begin{tabular}{|c|c|c|}
\hline & soft-bellows & metal-bellows \\
\hline weight (g) & 35 & 140 \\
\hline number of folds & 20 & 120 \\
\hline length (mm) & 8 & 160 \\
\hline stroke (mm) & 130 & 80 \\
\hline pressure proof (kgf/cm $)$ & 1.74 & 10 \\
\hline max output (kgf) & 28 & 17 \\
\hline pressure area (cm $)$ & 50 & 1.6 \\
\hline
\end{tabular}

$\mathrm{g}$ の $\mathrm{MH}$ 合金が封入されている. 容器には圧力を導くステ ンレスチューブと温度観測のための熱電対, そして, ペル チェ素子に電流を流すための端子がついている. 全体の重 量は電極を含め約 $250 \mathrm{~g}$ となっている.

\section{3 複合フィルム材を用いたソフトベローズ}

アクチュエータの装置を構成するパーツのほとんどは 金属材料である.我々は人体に装着することを考慮し，よ り軽く，柔軟性があり，そして，水素を透過しない非金属 素材でアクチュエータのベローズ部の作成を試みてきた. しかし，水素バリア性，柔軟性の両方を備えたベローズを 作ることは，単一素材では難しい，そこで，高分子複合材 料に着目した.

今回，ベローズ部を作成するにあたり，アルミ箔ラミネ ートフィルム（三菱ガス化学社製）を使用した。この素材 は, ポリエチレン (PE), アルミニウム (Al), ポリエチレ ンテレフタレート (PET) の三層構造のフィルムである. 水素透過性はアルミ䇴の厚さに依存寸るが, 我々はアルミ 箔厚さが $12 \mu \mathrm{m}$ のものを使用した.

このような材料を用い，直径 $100 \mathrm{~mm}$ ，段数 20 段のベロ 一ズを作成した，その外観を図 2 に示す．作成の際には， アルミ箔ラミネートフィルムの PE の層が $140^{\circ} \mathrm{C}$ 程で融解 する特性を活かし，熱圧着で形成した。

試作ベローズの重量やストローク，耐圧，最大出力と従 来の金属ベローズとの比較を表 1 にまとめた.この表から も分かるとおり，試作べローズ重量は金属ベローズと比べ ると約 4 分の 1 の $35 \mathrm{~g}$ となり，一層軽量となった。 また， ストローク/ベローズ全長も 30 倍以上となり，ウェアラ ブル性が向上した.

\section{3. アクチュエータの評価実験装置}

本研究で試作した MH アクチュエータを図 3 に示す. また，実験装置の概略を図 4 に示す．実験装置は主にここ れまで紹介してきた MHモジュールとソフトベローズ, そ

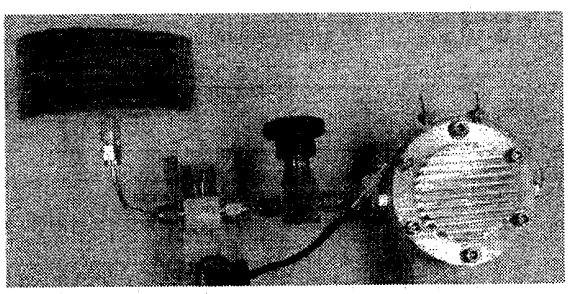

Fig.3 Photograph of a metal hydride actuator with soft-bellows Load cell

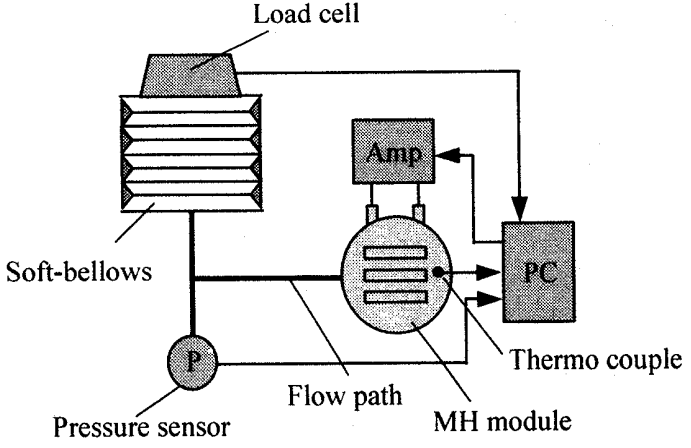

Fig.4 Experimental setup for the $\mathrm{MH}$ actuator れに測定部を加えた三つの部分から構成されている.

MH モジュール内部の温度が過度に上昇するのを防ぐ ために熱電対を設置し，観測を行った．また，MHモジュ 一ルに対する電流は，PC に接続したD Aボード（DATEL 社製，PC-412LV）より発生させた電圧信号を電流アンプ （KEPCO 社製，BOP20-20M）で電流信号に変換，増幅し て供給した。 MH モジュールから発生した水素解離圧の測 定には圧力センサ（共和電業社製，PGM-5K）を用いた。 さらに, 解離圧より発生する鉛直方向の出力は材料試験機 （A\&D 社製，STA-1225）により測定した.

\section{MHソフトアクチュエータの静的特性}

\section{1 ソフトベローズの耐久性}

試作したベローズの実用性を調べるために, 水素透過性 と耐屈曲特性について検証した。

まず，水素透過性を調べるために変位を $30 \mathrm{~mm}$ に固定 し， $7 \mathrm{~kg}$ ほどの荷重を加えた。変位はべローズを最も圧 縮した状態を $0 \mathrm{~mm}$ とする. 測定は約 250 時間連続で行っ た，その結果を図 5 に示す。この結果より，水素圧の減少 量を算出すると， $0.7 \%$ 程度であった。

試作したベローズの素材であるアルミ箔ラミネートに おいて最も懸念される弱点は, 屈曲・伸展の繰り返しによ るピンホールの発生である．耐屈曲特性を調べるために， まず，二つのソフトベローズを拮抗させて接続し，反復試 験中に常に内圧が一定になるようにした，そして，一方の ベローズに重りを載せ，もう一方のベローズを材料試験機 で繰り返し伸縮させた，その結果を図 7 に示す. なお，伸 縮動作はストローク $30 \mathrm{~mm}$, 変位速度 $30 \mathrm{~mm} / \mathrm{min}$, 繰り返 し数 3500 回で行った. 図 6 から分かるとおり，急激な変 位の減少はない. 従って, 3500 回の伸縮動作によっても ピンホールが発生していないことがわかった。 


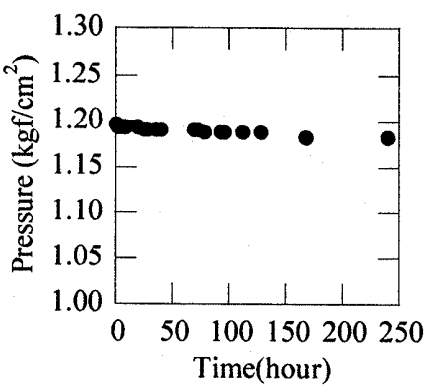

Fig.5 Time course of pressure in soft-bellows

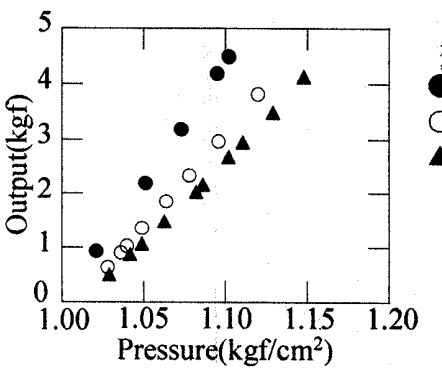

Fig.7 The relationship between internal pressure of $\mathrm{MH}$ module and output of $\mathrm{MH}$ actuator

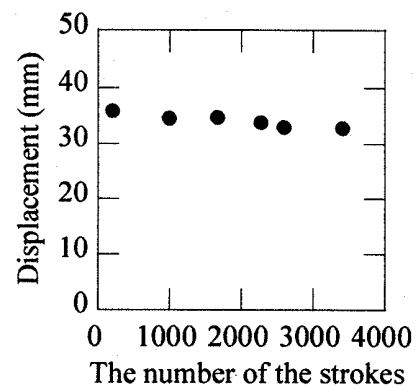

Fig.6 The relationship between number of strokes of soft-bellows and output displacement

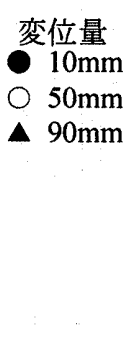
ad

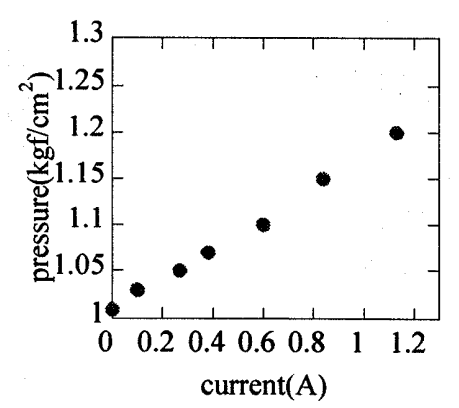

Fig.8 The relationship between current to $\mathrm{MH}$ module and output of $\mathrm{MH}$ actuator
以上より，複合フィルム材を利用したベローズは 10 日 間という使用条件の下では, 十分に連続して利用できるこ とが確認できた。

\section{2 出カに対する圧力の関係}

次に, 試作したベローズに関し, 圧力ー出力の関係を調 べた. 変位を $10 \mathrm{~mm}, 50 \mathrm{~mm}, 90 \mathrm{~mm}$ の位置でベローズを固 定したときの水素圧と出力の関係を図 7 に示す.この図よ り, 水素圧を高めるとそ机に比例して出力も増加すること がわかった.また, 受圧面を大きくすることが容易なため, 少ない圧力の変化で大きな出力が引き出せる. 従って, ソ フトベローズ型は金属ベローズに比べて, MH モジュール へ対する入力電流も少なく, 省電力であることもわかった.

\section{MHソフトアクチュエータの動的特性}

\section{1 制御システム}

試作したソフトベローズの動特性を調べるために, 入力 電流と発生圧力の関係を調べた（図 8)。この関係は水素 解離圧を一定に保ち，MH モジュールに印加した電流を測 定したものである．実用性を考慮して，比例・積分動作を 加えた PI 制御を用いた。ここで，PI 動作を行う際には， ソフトウェア（National Instrument 社製，LabVIEW6. 02） を用いて，プログラムを作成した．また，入力電流 I と圧 力 $\mathrm{P}$ の関係は図 8 より（2）式で近似できる.

$$
\mathrm{P}=\mathrm{al}^{2}+\mathrm{bl}+\mathrm{c}
$$

PI 制御による各パラメータの決定には, 目標圧力值より のオーバーシュートが $1 \%$ 末満になるように設定した.こ れは，人体に装着する場合の安全性を考慮し，装着時に過

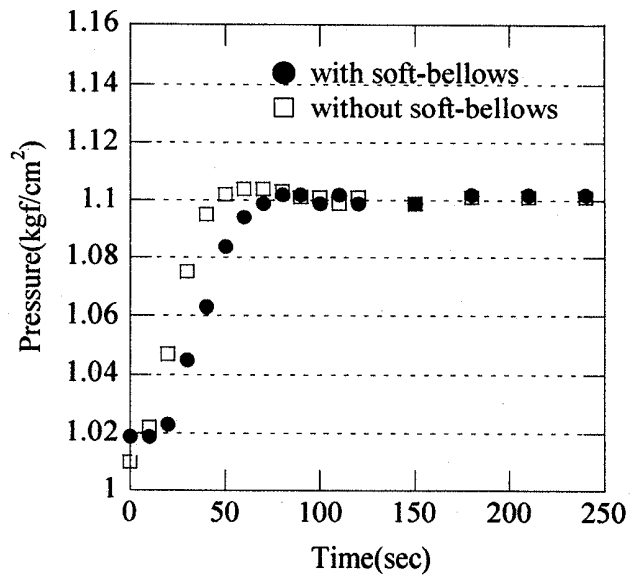

Fig.9 The time pattern of pressure of a MH actuator by step input current

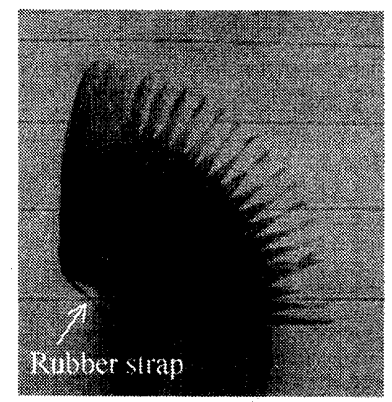

Fig.10 Bending structure of the $\mathrm{MH}$ actuator 負荷がヒトの関節に掛からないようにするためである.今 回は，変位を $10 \mathrm{~mm}$ に固定し，目標圧力を $1.10 \mathrm{kgf} / \mathrm{cm}^{2} に$ 設定した.この圧力は出力に換算すると $4 \mathrm{kgf}$ 程度である.

\section{2 ステップ応答}

MHモジュールにソフトベローズを接続しない時と接 続した時の二つの条件でステップ入力に対する応答性を 調べる実験を行った，その結果を図 9 に示す．この図から も分かるとおり，べローズを付けないときは，直線的に圧 力が上昇し，目標圧に達している．そして，120 秒後には すでに出力が一定で安定していることが確認できる、これ から，本実験で使用した PI 制御は適切に作動しているこ とがわかった。

次に，ソフトベローズをMH モジュールに接続して設置 してステップ応答を調べた.この際に，オーバーシュート が 1 \%未満になるように設定した. ベローズを接続しない ときと比べると立ち上がりが少し遅れているのが確認で きる、これは，ソフトベローズの柔軟性のため，僅かなが らべローズの外形が変形したためと考えられる。しかしな がら，ソフトベローズを接続したときには，接続しないと きと同様に 120 秒後には安定している.このことからソフ トベローズを出力部に利用しても $\mathrm{MH}$ モジュール内で生 じる出力特性を損なうことなく出力端に力を伝達できる ことが分かった。

\section{6. ヒトの関節への装着を考慮した曲げ機構}

これまで試作したベローズが従来の金属ベローズと比 
べ軽量・小型化され, 人体に装着できる可能性を確認した. ここで, 実際にどんな機構で装着させたら良いかを考察す る.

関節リハビリ機器などに適用する場合, 一軸の運動では 関節の複雑な動きをサポートすることは難しく, 多くの機 構を要するため出力の損失が大きい. 今回試作したベロー ズはその柔軟性から自在に曲げることが可能であり, 複雑 な機構なしで直接的に関節運動をサポートできると考え られる、そこで，関節の動きに沿うようにべローズを曲げ るために，弾性材料（例えば，ゴムひも）を用いて拘束を 加えることを提案する. ベローズが伸縮する際に，一部分 のみ拘束されるため，その方向に曲げることができる。こ こで拘束に弾性材料を提案したのは，関節の複雑な動きに 柔軟に対応できるストロークを持たせるためである. 実際 にベローズに拘束を加えて伸張させたものを図 10 に示す このように拘束を加えて直接曲げることにより，より関節 の動きにマッチした機構を作ることができる．また，拘束 部の弾性係数を変えることにより, 曲率の調整も可能であ る.

\section{7. 肘関節リハビリ機器への応用}

このような曲げ機構を含めたウェアラブルアチュエー タの応用として CPM(Continuous Passive Motion)機器が挙 げられる ${ }^{[4]}$.これは肘関節などの手術後に，リハビリ方法 として広く用いられている機器である. 手術後に, そのま ま放置しておくと関節硬縮などの症状が起き, 関節を動か す際に疼痛を感じたり, 十分な関節可動域が得られないこ とがある。これを防ぐために，術後早期に理学療法士が絶 えず関節をゆっくりと動かすことが効果的である.しかし， 理学療法士が長時間ゆっくりとした繰り返し動作のリハ ビリを行うことは難しく，負担も大きい，そのため，CPM 機器と呼ばれる関節リハビリ機器が開発され, 臨床的にも 高い効果が報告されている.

これまでの CPM 機器は電磁モータを使用しているため にコンプライアンスが少なく, 装置自体が施設向けの大き なものとなっている。しかしながら，MHアクチュエータ を用いることにより， $\mathrm{H}_{2}$ ガスの緩衝作用を生かした柔軟 なアクチュエータを設計が可能であり，図 11 のように人 体に装着できるほど軽量かつ小型な CPM 機器の設計が可 能である ${ }^{[5][6] . ~}$

\section{8. まとめ}

本研究の範囲内で以下のことが明らかになった。

（1）アルミ䇴ラミネートを用いて作成したベローズの水 素透過性や耐屈曲特性は一週間程度であれば連続 稼動に十分に耐え得る性能を持ち，金属べローズに 比べ，ウェアラブル性が向上した。

（2）圧力ー出力特性より，僅かな圧力で大きな出力が取 り出すことができる．また，入力電流も少なく，省 電力である。
（3）ソフトベローズを用いることにより, MH 合金自体 の出力特性とほぼ同じ特性が得られることが分か った.

（4）人体に装着させるために曲げ機構を提案した. ベロ 一ズの一部に拘束を加えることにより，試作べロー ズの柔軟性を生かした曲げ機構が考えられる.

今後の展望として, 提案した曲げ機構について様々な拘 束方法を検証し, ウェアラブルな関節リハビリ機器を設計 し, 実際に設計した関節リハビリ機器の臨床評価を行って いきたい。

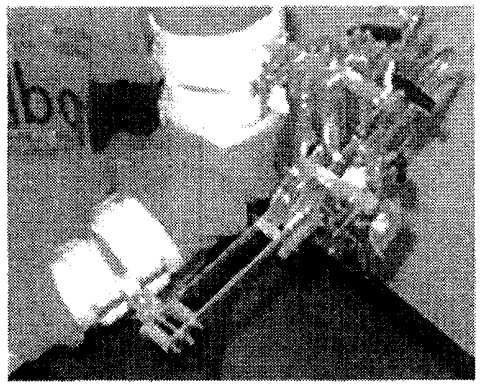

Fig.11 An elbow joint rehabilitation system using an $\mathrm{MH}$ actuator

\section{謝辞}

本研究の一部は NEDO 平成 14 年産業技術研究助成事 業の補助を受けた．記して感謝する。

\section{参考文献}

[1]佐々木，川嶋，青山，伊福部，小川：水素吸蔵合金 を利用したアクチュエータの開発，日本ロボット学 会誌, vol.7, No.5, pp.469-500(1986)

[2] 緒方, 井野, 山田, 泉, 吉永, 河野, 伊福部: 複合 フィルム材料を用いた柔らかい水素吸蔵合金アクチ ユエータの開発, 精密工学会春季大会学術講演会講 演論文集, pp.439(2002)

[3] 大西敬三: 水素吸蔵合金の応用技術，シーエムシー 出版, pp.203(1994)

[4] R.B.Salter et al.: Clinical application of basic research on contiuous passive motion for disorders and injuries of synovial joints: a preliminaryreport of a feasibility study, Journal of Orthopaedic Research, vol.1, pp.325-342 (1984)

[5] S.Ino, T.Izumi, M.Takahashi and T.Ifukube: Design of an Actuator for Tele-existence Display of Position and Force to Human Hamd amd Elbow; Journal of Robotics and Mechatronics, vol.4, No.1, pp.43-48 (1992)

[6] 奥村, 敦賀, 井野, 伊福部, 田中, 泉, 河野, 室: 肘 関節リハビリテーションシステムのための小型 $\mathrm{MH}$ アクチュエータの開発，ヒューマンインターフェー 六学会研究報告集, vol.1, No.5, pp.53-58(1999) 